\title{
Effect of defect density in different layers and ambient temperature of $n$ - $i$ - $p$ a-Si single junction solar cells performance
}

\author{
Shalini Dubey ${ }^{*}$, Arpit Swarup Mathur $^{2}$, Nidhi $^{3}$, BP Singh $^{4}$ \\ ${ }^{1,2,3,4}$ Department of Physics, Institute of Basic Sciences, Dr. B.R. Ambedkar University, Agra-282002, India \\ *Corresponding author: dubey.shalini12@gmail.com
}

ORCID ID- 0000-0002-9012-7763

Available online at: www.isroset.org

Received: 02/Apr/2019, Accepted: 13/Apr/2019, Online: 30/Apr/2019

\begin{abstract}
In this paper simulation study of optimized n-i-p a-si single junction solar cell which having defect density in different layers. From the simulation result, it was found that the conversion efficiency is affected due to the presence of defect density in different layers. The maximum conversion efficiency is found $24.74 \%$ and $22.94 \%$ at without defect density at $0^{\circ} \mathrm{C}$ and $30^{\circ} \mathrm{C}$ respectively, while the conversion efficiency become zero in p-type front layer in $10^{22} \mathrm{~cm}^{-3}$ defect density and $11.35 \%$ in i-type absorber layer in $10^{-21} \mathrm{~cm}^{-3}$ defect density. It is clear that the quality of absorber layer and front layer is the key factor in cell performance or efficiency improvement. These results are consistence with the fact that $\mathrm{n}$-i-p a-Si single junction solar cell with the higher defect densities and dislocation exhibits a lower efficiency of the cell.
\end{abstract}

Keywords: a-Si single-junction, defect density, conversion efficiency, SCAPS, BSF.

\section{INTRODUCTION}

The performance of any solar cell depends on the various parameters such as cell design, material properties and its fabrication technologies. From past to present there are so many solar cells are fabricated but the fabrication process time and costs are much more complicated and higher. So that simulation approaches are the most convenient solution in solar cells research processes. The simulation approach has become indispensable tool for design a high efficiency solar cell. Amorphous silicon (a-Si) thin film is the good entrant of solar cell applications. It has high absorption coefficient $\left(>10^{5} \mathrm{~cm}^{-1}\right)$, variable band gap and low temperature deposition potential. The first amorphous Silicon solar cell was grown on silane $\left(\mathrm{SiH}_{4}\right)$ plasma by Chittick[1]. The band gap of $\mathrm{Si}$ is varying from 1.1 to $1.8 \mathrm{eV}$ which is correlate with the incident light band gap. The conversion efficiency of solar cell is the consequential outcome of its open circuit voltage $\left(\mathrm{V}_{\mathrm{OC}}\right)$, Short circuit current density $\left(\mathrm{J}_{\mathrm{SC}}\right)$ and fill factor $(\mathrm{FF})$. For improving the converging efficiency, it is necessary to upgrade these parameters. Several groups also do good works on $n-i-p$ a-Si single junction solar cells which shows that the convergent efficiency varying with defect densities and ambient temprature[2-6]. In this present paper we study the effect of defect density (neutral defect) in different layers of n-i-p a-Si single junction solar cell used numerical simulation approach for $n-i-p$ a-Si single junction solar cell. As we know that the n-i-p configuration gives always better result than the $\mathrm{p}-\mathrm{i}-\mathrm{n}$ configuration. Because the first n-layer deposited on the substrate after the anti-reflactive layer following the moderately doped p layer and then the $\mathrm{p}$ - back surface field layer. The simulation result show that the $\mathrm{J}_{\mathrm{SC}}, \mathrm{V}_{\mathrm{OC}}, \mathrm{FF}$ and converging efficiency strongly depends on ambient temperature and defect density. When the ambient temprature is incresed the conversion efficiency become fall down. For the simulation process we used Solar cell Capacitance Simulators(SCAPS-1D) version-2.8, developed by Marc Burgelman and his team from department if electronics and information system (ELIS) University of Gent, Belgium. This simulation approach is very valuable tool in modeling of any thin film or a-Si solar cell[7]. In this tool from which we can simulate any solar cell up to seven layers[8]. Ambient temperature change playing the major role in solar cell performance[9].

\section{SOLAR CELL DESIGN AND FABRICATION}

Here we are using $n-i-p$ a-Si solar cell instead of $p-i-n$ a-Si solar cell. The improved photovoltaic performance of the $n-i-p$ solar cell is endorsed to two effects: foremost, advanced transparency of the n-type a-Si window layers compared to usual p-type 
microcrystalline silicon layers, allowing improved illumination diffusion through the window layer and a correspondingly advanced creation of photocurrent in absorbing layers; and following, high hole-drift mobility in the intrinsic absorbing layer, causing proficient collection of photocurrent[10]. Achieving the best photovoltaic performance of a cell under standard solar illumination, 1.5 AM and 1 sun, thickness and band gap of the $p, n$, and $i$-region then should be optimized. An intrinsic absorber layer (a-Si) is enclosed between a n-type (a-Si) and an p-type doped layer (a- Si). The thin n-layer functions as window layer through which the light enters. Photons that are immersed in i-layer generate an electron-hole pair. The electric field induced across i-layer by the $\mathrm{p}$ - and n-layers causes the electrons to drift towards the n-layer and the holes towards the $\mathrm{p}$ layer. At the doped layers, the charge carriers are composed by electrical acquaintances and contribute to the output power of the solar cell. In the device modeling, wide band gap a-Si is used as n-doped window layer to decrease absorption losses[11]. Moreover, Voc also increases for its wider band gap. It is well known that Voc is susceptible to p-layer and p/i interface. As optical absorption at the p-layer limits $J \mathrm{sc}$, wider optical gap material is always desired for improving $J_{\mathrm{sc}}[12]$. The p-type graded a-Si buffer layer was used to mitigate the p/i interface effect which has a great influence on Voc. In solar cells there is a problem of recombination at the rear end, just like when the charge carriers are somewhat away from field, they recombine instead of getting collected, which reduces the efficiency directly. To overcome this we use a BSF layer which is a highly doped layer at the rear end to reflect back the minority carriers and to attract the majority charge carriers. The BSF layer not only prevents the carrier recombination but also helps in mounting the efficiency of the solar cell and thus the presence of BSF layer is one of the necessities to have better performance from a solar cell[13]. The schematic of simulated device is shown in figure1. The design parameters have been adopted from some standard references (SCAPS-1D) to investigate the variation of efficiency, Voc, Jsc, and FF with the variation of doping densities of i-layer, and the dependence of efficiency on ambient temperature.

Fig. 1 Schematic diagram of $n-i-p$ a-Si solar cell

\begin{tabular}{|c|}
\hline Front contact \\
\hline n-type a-Si window layer \\
\hline p-a-Si buffer layer \\
\hline i-a-Si absorber layer \\
\hline p-type a-Si BSF \\
\hline Back contact \\
\hline
\end{tabular}

For proper optimization of the tandem cell, there are some parameters which are to be measured like Open circuit voltage $\left(\mathrm{V}_{\mathrm{OC}}\right)$, short circuit current density $\left(\mathrm{J}_{\mathrm{SC}}\right)$, fill factor $(\mathrm{FF})$ total current $\left(\mathrm{I}_{\text {total }}\right)$ and conversion efficiency $(\eta)$. These parameters are expressed as

$$
\begin{aligned}
& \mathrm{V}_{\mathrm{OC}}=\frac{n k T}{q} \ln \left(\mathrm{I}_{\mathrm{L}} / \mathrm{I}_{\mathrm{O}}+1\right) \\
& \mathrm{J}_{\mathrm{SC}}=\mathrm{qG}\left(\mathrm{L}_{\mathrm{n}}+\mathrm{L}_{\mathrm{p}}\right) \\
& \mathrm{FF}=\frac{\frac{\mathrm{q}}{\mathrm{nkT}}-\ln \left(\frac{q}{n k T}+0.72\right)}{\frac{q}{n k T}+1} \\
& \eta=\frac{\text { VocIscFF }}{\operatorname{Pin}}
\end{aligned}
$$

Where $G$ is generation rate, $L_{n}$ and $L_{p}$ are the electron and holes transmission length respectively, $I_{o}$ and $I_{L}$ are the dark saturation current and light generated current respectively, $\mathrm{n}$ is ideality factor, $\mathrm{kT} / \mathrm{q}$ is thermal voltage and $\mathrm{P}_{\text {in }}$ is input power. In order to improve the solar cell performance, light trapping is used to increase the short-circuit current density (Jsc). The opencircuit voltage (Voc) can be amplified by calculating the bulk properties of the absorber layer and the interface properties most particularly by reducing the defect density[14]. For highly efficient a-Si solar cells, an $i$ - $p$ interface region with low defect density is necessary[15].

The influence of the interfaces on the a-Si solar cell performance has been investigated extensively, in particular for an $i-p$ interface[16]. This interface is a hetero-junction with a band offset between the energy bands of a wide band-gap p type layer and the intrinsic layer[17]. Buffer layers are used to improve the interface properties. Besides this band offset, recombination in the highly defective interface region has a large influence on the cell performance[18-19]. This influence is mainly due to the high density of defects in this region, which act as recombination centers[20]. 


\section{SIMULATION RESULTS AND DISCUSSION}

The defect density is playing a very crucial role in solar cell performance. It is clearly shown in given table that when we increase the defect density in window layer, p-layer, i-layer and BSF layer, the conversion efficiency is decreased, Which shows that when a defect is present in any layer, conversing efficiency will be decreased automatically. Table 1 shows the conversion efficiency change in the presence of different defect densities in different layers of $n-i-p$ a Si single junction solar cell while in table 2 shows the conversion efficiency with different ambient temperature change.

From the fig. 2(a) it is clear that when a neutral defect density is present in window layer the there is no change but if we increase the density the efficiency is slowly decreases at the span $10^{15}$ to $10^{22} \mathrm{~cm}^{-3}$. After $10^{22} \mathrm{~cm}^{-3}$ the efficiency becomes constant. Fig. 2(b) indicates that the when the defect is present in p-type front layer, the efficiency decreases at the span $10^{11}$ to $10^{22} \mathrm{~cm}^{-3}$ but from $>10^{16} \mathrm{~cm}^{-3}$ efficiency decrease rapidly and at $>10^{22} \mathrm{~cm}^{-3}$ it becomes zero which is the most important and interesting factor. This graph shows very clearly that the, when defect is present in the front layer the efficiency drops very rapidly. Fig 2 (c) reported that the defect density is mostly affected the intrinsic layer at the span $10^{9}$ to $10^{21} \mathrm{~cm}^{-3}$ while the Fig. 2 (d) shows that the defect density is not much affect to BSF.

Table 1 different defect densities present in different layers individually

\begin{tabular}{|l|l|l|l|l|l|}
\hline S.N. & $\begin{array}{l}\text { Defect } \\
\text { density } \\
\left(1 / \mathrm{cm}^{3}\right)\end{array}$ & $\begin{array}{l}\text { Efficiency when defect } \\
\text { present onlyin n-type } \\
\text { window layer }(\%)\end{array}$ & $\begin{array}{l}\text { Efficiency when defect } \\
\text { present only in p-type } \\
\text { front layer }(\%)\end{array}$ & $\begin{array}{l}\text { Efficiency when defect } \\
\text { present only in i-type } \\
\text { absorber layer }(\%)\end{array}$ & $\begin{array}{l}\text { Efficiency when defect } \\
\text { present only in p-type } \\
\text { BSF }(\%)\end{array}$ \\
\hline 1. & $\begin{array}{l}\text { Without } \\
\text { defect }\end{array}$ & 22.94 & 22.94 & 22.94 & 22.94 \\
\hline 2. & $10^{9}$ & 22.94 & 22.94 & 22.94 & 22.94 \\
\hline 3. & $10^{10}$ & 22.94 & 22.94 & 22.90 & 22.94 \\
\hline 4. & $10^{11}$ & 22.94 & 22.91 & 22.60 & 22.94 \\
\hline 5. & $10^{12}$ & 22.94 & 22.70 & 21.24 & 22.94 \\
\hline 6. & $10^{13}$ & 22.94 & 21.70 & 18.60 & 22.94 \\
\hline 7. & $10^{14}$ & 22.94 & 19.28 & 15.93 & 22.94 \\
\hline 8. & $10^{15}$ & 22.94 & 14.93 & 13.68 & 22.94 \\
\hline 9. & $10^{16}$ & 22.91 & 8.81 & 12.27 & 22.92 \\
\hline 10. & $10^{17}$ & 22.62 & 5.08 & 11.66 & 22.62 \\
\hline 11. & $10^{18}$ & 20.93 & 2.60 & 11.45 & 20.93 \\
\hline 12. & $10^{19}$ & 18.50 & 1.21 & 11.38 & 18.50 \\
\hline 13. & $10^{20}$ & 17.34 & 0.40 & 11.36 & 17.34 \\
\hline 14. & $10^{21}$ & 16.54 & 0.04 & 11.35 & 16.54 \\
\hline 15. & $10^{22}$ & 15.99 & 0.00 & 11.35 & 15.99 \\
\hline 16. & $10^{23}$ & 15.99 & 0.00 & 11.35 & 15.73 \\
\hline
\end{tabular}

Table 2 efficiency behavior with ambient temperature change

\begin{tabular}{|l|l|l|}
\hline S.No & Temperature $\left({ }^{\circ} \mathrm{C}\right)$ & Efficiency $\eta(\%)$ \\
\hline 1. & 30 & 22.94 \\
\hline 2. & 25 & 23.07 \\
\hline 3. & 20 & 23.39 \\
\hline 4. & 15 & 23.72 \\
\hline 5. & 10 & 24.04 \\
\hline 6. & 5 & 24.36 \\
\hline 7. & 0 & 24.74 \\
\hline
\end{tabular}

Last fig. 3 shows the variation of temperature which affects the conversion efficiency. From this graph it is clear that the conversion efficiency is directly depends on cell temperature. At $30^{\circ} \mathrm{C}$ the conversion efficiency is $22.94 \%$ but when we decrease the temperature the conversion efficiency improved and at $0^{\circ} \mathrm{C}$ it becomes the record efficiency $24.74 \%$. 


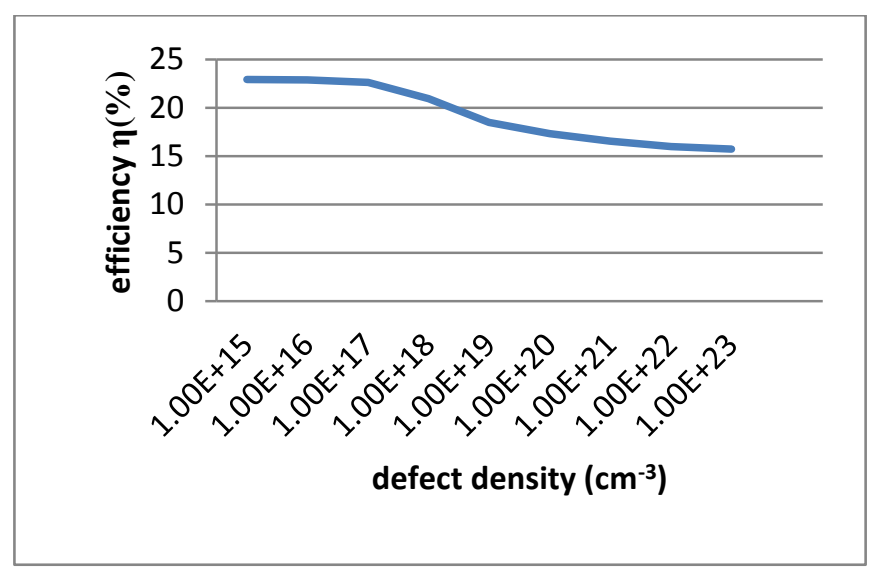

Fig. 2 (a) efficiency-defect density curve which shows efficiency when defect density present in n-type window layer

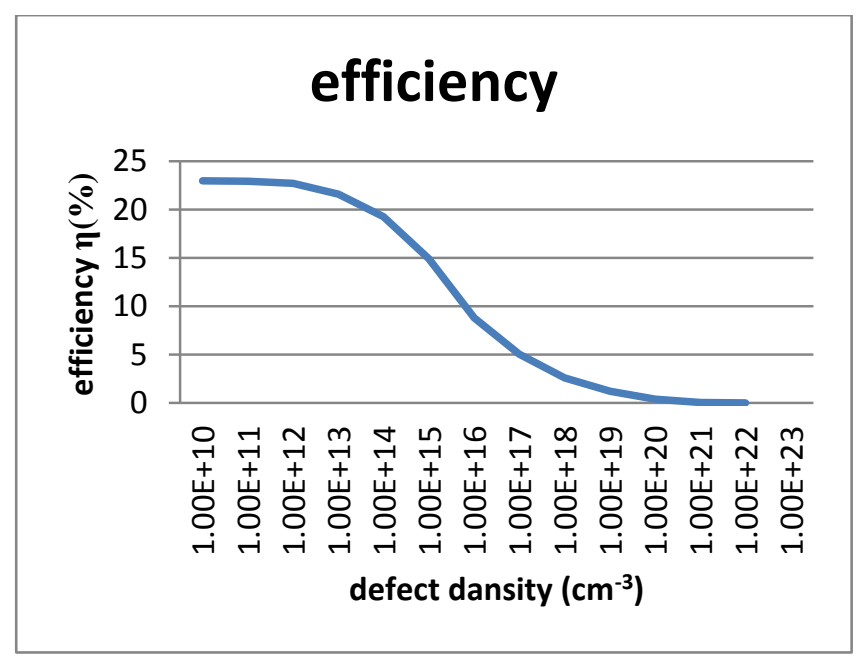

Fig. 2 (b) efficiency-defect density curve which shows efficiency when defect density presentin p-type front layer

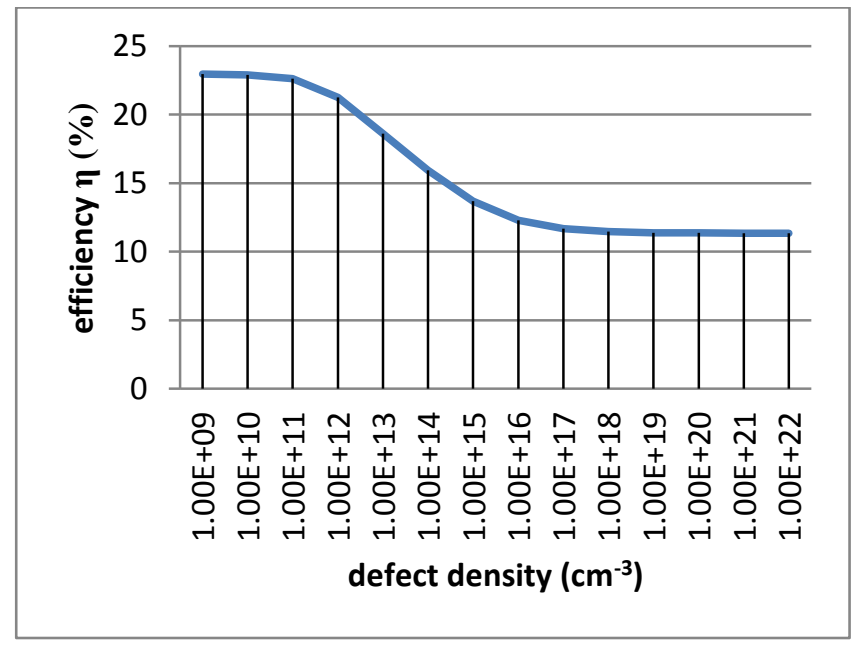

Fig. 2(c) efficiency-defect density curve which shows efficiency when defect density present in i-layer 


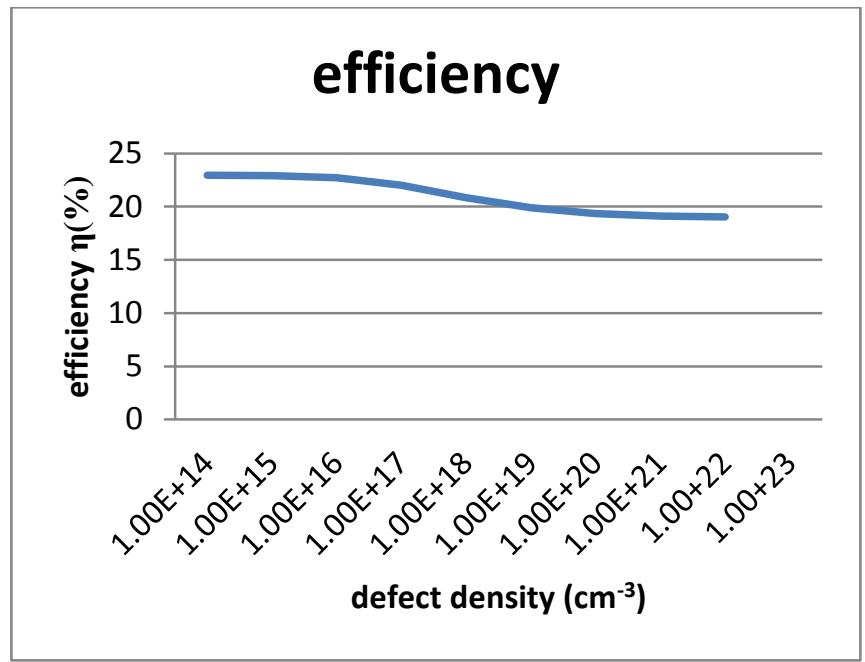

Fig. 2(d) efficiency-defect density curve which shows efficiency when defect density present in BSF layer

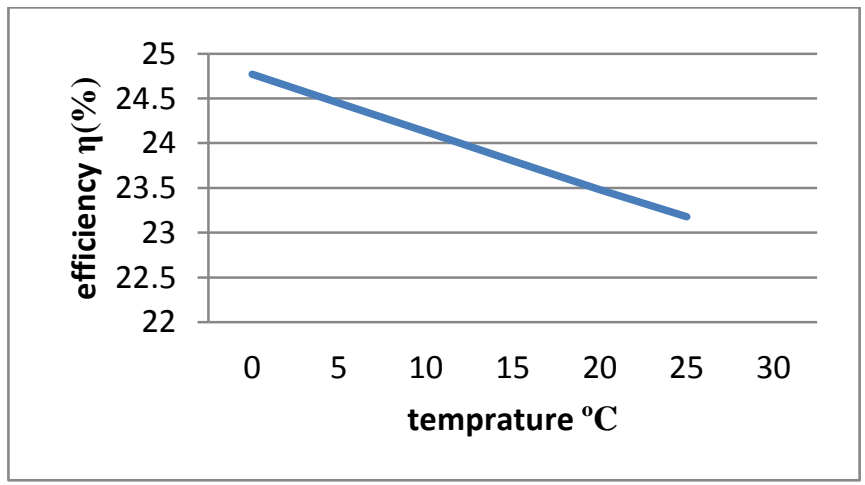

Fig. 3 temperature and efficiency dependency

\section{CONCLUSION}

The single-junction a-Si solar cell has been designed and finally fabricated to investigate the design validation for higher efficiency. Variation of cell characteristics parameters in terms of defect density in $\mathrm{n}$-window layer $p$ - front layer, $i$-layer, $\mathrm{p}$ BSF layer, and cell has been calculated and it was found that defect density is strongly affected the p-front layer and i-layer. Efficiency becomes zero when we increase the defect density ratio in p-type front layer. There are different defect densities where they do not affect the cell's conversion efficiency. We also investigate the ambient temperature effect on solar cell conversion efficiency, and it shows that the temperature is directly proportional to conversion efficiency. We found that at $30^{\circ} \mathrm{C}$ the conversion efficiency is $22.94 \%$ but when temperature is down at $0^{\circ} \mathrm{C}$ the record efficiency increased at $24.76 \%$. Thus we can say that the defect density and ambient temperature both play the major role in solar cell performance.

\section{REFERENCES}

[1] R. C. Chittick, J. H. Alexander, and H. F. Sterling, "The preparation and properties of amorphous silicon," Journal of the Electrochemical Society, vol. 116 No. 1, pp. 77-81, 1969.

[2] S. Zhong, X. Hua, and W. Shen, Simulation of High-Efficiency Crystalline Silicon Solar Cells With Homo-Hetero Junctions, IEEE Transactions on Electron devices, vol. 60 No. 7, p.p. 2104, july 2013.

[3] A. Fell, K. R. McIntosh, P. P. Altermatt, G. J. M. Janssen, R. Stangl, A. Ho-Baillie, H. Steinkemper, J. Greulich, M. M“uller, B. Min, K. C. Fong, M. Hermle, I. G. Romijn, and M. D. Abbott, Input Parameters for the Simulation of Silicon Solar Cells in 2014, IEEE journal of photovoltaics, vol.5, No.4, p.p. 1250, july 2015.

[4] S. Sepeai, S.H.Zaidi, M.K.M.Desa, M.Y.Sulaiman, N.A.Ludin, M.A. Ibrahim, K.Sopian, Design Optimization of Bifacial Solar Cell by PC1D Simulation, Journal of Energy Technologies and Policy, vol.3, No.5, p.p. 1-11, 2013.

[5] H. Singh, V. Kumar, Effect of Ni doping on the photovoltaic conversion efficiency of ZnO nanostructured dye sensitized solar cells, International Journal of Scientific Research in Physics and Applied Science, vol. 6, No. 3, pp. 50-54, 2018. 
[6] T. H. Talukdar; R. Siddique; M. Hasan, Study of Single Junction Solar Cell Characteristics Varying Different Parameters, 2nd Int'l Conf. on Electrical Engineering and Information \& Communication Technology (ICEEICT) 2015 Jahangir nagar University, Dhaka-I 342, Bangladesh, 21-23 May 2015.

[7] M. Burgelman, P. Nollet and S. Degrave, "Modeling of polycrystalline semi conductor solar cells", Thin Solid Films, vol. 361, No.362, pp.527-532, 2000.

[8] A. Niemegeers and M. Burgelman, "Numerical modeling of ac-characteristics of CdTe and CIS solar cells", 25" IEEE Photovoltaic specialist Conference Washington DC 1996, pp. 901-904,1996.

[9] M. A. Green, "General temperature dependence of solar cell performance and implications for device modeling" Prog Photovoltiac,vol.11, No.5,pp.333-340, 2003.

[10] P.Štulik and J. Singh, A simple method to simulate the influence of defect on the short circuit current in amorphous silicon solar cells, J. NonCrysta Solids, vol.226,No.3 pp.299-303,1998.

[11] H. Taniguchi, M.Konagai, K. S. Lim, P. Sichanugrist, K. Komori and K. Takahashi, Junction Properties of n-i-p and p-i-n Amorphous Si Solar Cells Prepared by a Glow Discharge in Pure Silane, Japanese J Appl Phys, vol. 21,pp.219-224,1982.

[12] H. Arai, M. Ishii, H. Shinohara, and S. Yamazaki, A Single p-i-n Junction Amorphous-Silicon Solar Cell with Conversion Efficiency of 12.65\%, IEEE Electron Device Letters, vol.12 No.8, 1991.

[13] T. Itoh, K. Fukunaga, Y. Katoh, T. Fujiwara, and S. Nonomura, "Doping of a-SiCX:H films including $\mu \mathrm{c}-\mathrm{Si}: \mathrm{H}$ by hot-wire CVD and their application as a wide gap window for heterojunction solar cells," Solar Energy Materials and Solar Cells, vol. 74No.1-4,pp.379-385, 2002.

[14] J. Verma, P. Dey, A. Prajapati, T. D. Das, Multi BSF Layer InGaP/GaAs High Efficiency Solar Cell, 2017 11th International Conference on Intelligent Systems and Control (ISCO),2017.

[15] S. Y. Myong, S. S. Kim, and K. S. Lim, "Improvement of p-i-n-type Amorphous Silicon Solar Cell Performance by Employing Double Silicon-carbide Player Structure"J. Appl. Phys. vol. 95, pp.1525-1531, 2004.

[16] A. Defresne, O. Plantevin, I. P. Sobkowicz, J. Bourçois, P. Roca iCabarrocas, "Interface defects in a-Si:H/c-Si heterojunction solar cells", Nuclear Instruments and Methods in Physics Research B, vol. 365, part-A, pp. 133-136, 2015.

[17] W. Ma, S. Aoyama, H. Okamoto, and Y. Hamakawa, "A study of interface properties in a-Si solar cells with $\mu$ c-Si(C)" Sol. Energy Mater. Sol. Cells, vol. 41, pp. 453-457, 1996.

[18] N.Palit and P. Chatterjee, "Computer analysis of a-Si:Ha-Si:H $p-i-n$ solar cells with a hydrogenated microcrystalline silicon $p$ layer, $J$ Appl. Phys., vol. 86, pp. 6879-6885, 1999.

[19] T. Walter, R. Herberholz, C. Muller, and H. W. Schock, "Determination of defect distributions from admittance measurements and application to $\mathrm{Cu}(\mathrm{In}, \mathrm{Ga}) \mathrm{Se}_{2}$ based heterojunctions J. Appl. Phys., vol. 80, pp.441-448, 1996.

[20] K. Decock, S. Khelifi, M. Burgelman, "Modelling multivalent defects in thin film solar cells", Thin Solid Films, vol.519, pp.7481-7484, 2011.

\section{AUTHORS PROFILE}

Ms Shalini Dubey has completed her B.Sc. M.Sc.(physics) and M. Ed from Dr Bhim Rao Ambedkar University Agra. She is currently pursuing her Ph.D.(physics) from the Department of Physics, Institute of Basic Sciences, Dr Bhim Rao Ambedkar University Agra. Her research work is maily emphasis on the solar cell efficiency improvement techniques. She has published 03 research papers in reputed international research journals and conferences including $106^{\text {th }}$ ISCA at LPU phagwara

Mr Arpit Swarup Mathur has completed his B.Sc. M.Sc. and M. Phil (physics) from the Dr Bhim Rao Ambedkar University Agra. Currently he is pursuing his Ph.D. (physics) from Dr Bhim Rao Ambedkar University Agra. His main research work is focused on simulation techniques in solar cells. He has published 06 research papers in reputed international research journals and conferences

Ms Nidhi has completed her B.Sc. M.Sc and M.Phil(physics) from the Dr Bhim Rao Ambedkar University Agra. She is also qualified GATE and JEST exams. She is currently working on nanostructure QD solar cells with the help of various simulation approaches. She has published 06 research papers in various reputed international research journals and conferences.

Prof. B.P. Singh is currently working as Professor of Physics at Department of Physics, Institute of Basic Sciences, Dr. B.R. Ambedkar University, Agra, India. He has a teaching and research experience of over 25 years. He has guided over 25 Ph.D. thesis and over 125 M.Phil. dissertations. He has more than 40 research papers published in various national and international journals. His areas of interest include Material Science, Solar Energy, Nanotechnology, Electronics and other related fields. He is presently working in the field of Solar Energy and Nanotechnology.
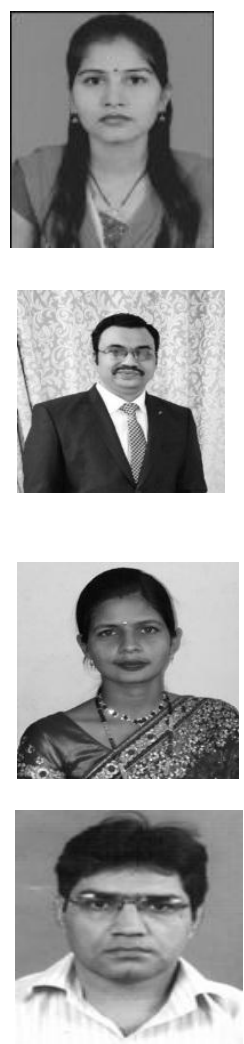